\title{
Discussion on Classical and Real Education in Russia in the Second Half of the 19th Century
}

\author{
Konstantin Fedorov \\ National Research University \\ Moscow State Technical University \\ named after N.E. Bauman \\ Moscow, Russia \\ E-mail: fedorov@live.ru
}

\author{
Tatyana Suzdaleva \\ National Research University \\ Moscow State Technical University \\ named after N.E. Bauman \\ Moscow, Russia \\ E-mail: syzdalev@list.ru
}

\begin{abstract}
The article is devoted to the problem of choosing the model of secondary education in Russia in the second half of the 19th century. The authors analyze the discussion between supporters of classical and real (practically oriented) education, the goals and results of school reforms of the 19th century, the activity of the Ministry of Public Education. They come to the conclusion that the dispute about the relationship between classical and real (practically oriented) education was not resolved until 1917.
\end{abstract}

Keywords-classical and real education; practically oriented education; Ministry of Public Education; school reforms; gymnasiums; real school; practically oriented school

\section{INTRODUCTION}

The abolition of serfdom in Russia in 1861 and the industrial revolution in Russia contributed to the acceleration of the development of the factory industry. Industrial modernization dramatically increased the prestige and relevance of the profession of an engineer. In the second half of the XIX century in Russia, new higher technical educational institutions were opened [1]. The secondary school was to prepare its graduates for engineering education. The real classes, opened in gymnasiums in 1839, did not cope with the solution of this problem.

Extensive literature is devoted to the history of the Russian school. The pre-revolutionary official historiography was mostly apologetic, it uncritically assessed the government policy in the sphere of education, the activities of the Ministry of Public Education. Soviet historians, on the contrary, emphasized the shortcomings of the old school, ignoring its strengths. Only in recent decades there have developed the conditions that allow an objective assessment of the historical experience of Russian pedagogy, which is reflected in the works of contemporary Russian authors. [2].

The purpose of this article is to analyze the reasons, content and results of the discussion on classical and real education in Russian society in the second half of the 19th century.

\section{DISCUSSION ON CLASSICAL AND REAL EDUCATION IN THE PERIOD OF PREPARING AND CARRYING OUT THE REFORM OF 1864}

The plans aimed at convergence of school education with the needs of industry, caused mixed reactions from the pedagogical community. Supporters of classical education feared that the transition to real education would weaken the moral education of youth, inextricably linked, in their opinion, with the study of ancient languages and culture. A wonderful surgeon and teacher N.I. Pirogov was one of the supporters of classicism. He argued that the main goal of education is to "make us people", which, in his opinion, "cannot be achieved by any real school in the world." $\mathrm{He}$ treated classicism as a humanitarian ("universal") education [3]. The editor of Moskovskie vedomosti M.N. Katkov, who had a reputation as a mouthpiece of conservatives, declared that classical education "is important not only for the career of a political figure, or lawyer, or a qualified doctor, or a natural scientist; it is recognized as a necessary condition for the higher development of technical activity "[4]. In the study of ancient languages, M.N. Katkov saw the pledge of mental and moral education of youth and considered natural sciences as a breeding ground for nihilism [5].

However, many educators and members of the public advocated the rapprochement of the school with the realities of modern life. K.D. Ushinsky supported the idea of N.I. Pirogov that "any kind of special education must be preceded by humane upbringing," but he categorically objected to the identification of the humanitarian education with the study of ancient languages. A well-known teacher urged "to put at the head of humane education" the study of the native language. $\mathrm{He}$ reasonably believed that the intention to make the knowledge of classical languages the necessary condition for admission to the university will only "uselessly make it difficult for many applicants to enter it" [6].

Taking into account the dissatisfaction of the public with the state of gymnasium education, the Ministry of Public Education started to develop the school reform. By February 1860, the "Draft Charter of Primary and Secondary Training Schools" was prepared. It provided for the creation of eightyear gymnasiums, in which the natural-mathematical and 
philological departments had to operate in the last three years of training. The project was sent out to all pedagogical councils and published in the periodical press. The Ministry recommended to analyze "the project completely freely, without any constraint on any part, and not only the details, but also the whole education system outlined in the draft" [7].

The proposals of the Ministry of Public Education aroused wide resonance. The authors of the project were criticized for eclecticism, for the lack of connection between education and life, for the fear of spreading real knowledge in the Russian school. Reviews of the project, including the critical ones, were published in the journal of the Ministry [8]. Different views on the reform of secondary education existed in the ministry itself.

In 1862 the "Draft Statute of General Educational Institutions" was submitted to the public. It proposed to divide the gymnasium into a philological one with the study of two ancient languages and a real one with the study of Latin.

Naturally, the question of the correlation of classical and real education was again at the heart of the discussion. The defenders of classical education were convinced that the study of ancient languages serves "to strengthen the moral ideals of the youth." [9] The main shortcoming of real education they considered "one-sided utilitarianism." Supporters of "realism" believed that education should not be separated from the practical needs of life. The project of the Ministry of Public Education did not satisfy either party [10].

The Ministry of Public Education faced a very difficult task. It was necessary to modernize the education system on the basis of a reasonable compromise between the two types of secondary school - classical and real. In 1863 the third document entitled "Draft Statute of Gymnasiums and Progymnasiums" was prepared and submitted to the State Council for discussion. On November 19, 1864 it was approved by Emperor Alexander II and received the force of law.

The statute provided for the division of gymnasiums into three types: 1) a classical gymnasium with two ancient languages; 2) a classical gymnasium with one Latin language; 3) a real (practically oriented) gymnasium without ancient languages. In the real gymnasium, special attention was paid to the study of mathematics, physics, natural history, and drawing. The right to enter universities gave only the certificate of graduation from the classical gymnasium. After graduating from the real gymnasium it was possible to enter higher specialized educational institutions [11]. Thus, the resolution of the dispute between supporters of "classicism" and "realism" was granted to the experience.

\section{DISCUSSION ON THE CHARACTER OF SECONDARY EDUCATION IN THE POST-REFORM PERIOD}

The practice revealed the serious shortcomings of the reform of 1864. Special discontent was caused by the prohibition for real gymnasiums' graduates to enter universities, which led to the outflow of students from them. However, D. A. Tolstoy, who held the post of Minister of
Public Education in 1866-1880, instead of attempts to raise the level of teaching in real gymnasiums, sought to exclude them from the system of secondary general educational institutions. Real gymnasiums had not yet managed to get the first graduates, but there had already been decided to transform them into real training schools.

In February 1871, the projects of D.A. Tolstoy were submitted to the State Council. The first document concerned changes and additions to the "Statute of Gymnasiums and Progymnasiums" of November 19, 1864. The second was a "Draft Statute of Real Training Schools". In April 1871, five meetings of the Senate Special Committee of the State Council took place, at which the projects of the Ministry of Public Education were considered. The views of the members of the special meeting were divided. Six of its members, including the military minister D.A. Milyutin and former Minister of Education of A. V. Golovin, opposed the proposals of D. A. Tolstoy, who insisted that only classical gymnasiums can function as general secondary schools. They considered it necessary to preserve real gymnasiums with an 8-year course of study and more thorough than in classical gymnasiums teaching of mathematics, natural sciences, Russian and modern foreign languages and drawing. They pointed out that in England and Germany, which D. A. Tolstoy referred to as proof of his rightness, real gymnasiums are opened on an equal footing with the classical ones. D. A. Milyutin rejected the statement of the Minister of Education about the direct connection of realism in education with materialism and nihilism [12].

Moreover, the opponents of the Minister of Education advocated the introduction of Latin in real gymnasiums for those students who wish to enter the university faculties of physics and mathematics or medicine, or to enter the medical and surgical academy. Nine members of Senate Special Committee voted for the submitted projects, six members were against them. In the general meeting of the State Council, the majority (29 versus 18) voted against D.A. Tolstoy, who demanded to admit to the "temple of science" (universities) only those who studied ancient languages. However, Alexander II's resolution demanded: "To fulfill according to the opinion of 19 members". On June 19, 1871 amendments and additions to the Statute of 1864 were approved. On July 30 the "Statute of Gymnasiums and Progymnasiums of the Ministry of Public Education" was approved.

Discussion of the "Draft Statute of Real Training Schools" continued at a meeting of the Senate Special Committee of the State Council on February 17, 1872. This time only six votes were given for the minister's proposals, nine were against. On April 3, D. A. Tolstoy came across active resistance from the majority members of the general meeting of the State Council. His opponents proposed to establish the real training schools as parallel to the gymnasiums secondary schools with intensive teaching of mathematics and natural science. Again, Alexander II took the side of the minority. On May 15, 1872, he approved the "Statute of Real Training Schools of the Ministry of Public Education" [13]. 
The Statute read: "Real training schools aim to provide the student with a general education, adapted to practical needs and to acquire technical knowledge" [14]. In accordance with the Statute, the training course in real training schools lasted six years (at the gymnasium it was eight years). The "realists" were given more intensive than in gymnasiums courses of mathematics, science, and drawing, two new foreign languages were mandatory (in the absence of the ancient ones). At real training schools were created laboratories and workshops. Graduates, who completed the 7 th additional grade, had the right to enter technical colleges, but not universities.

Real training schools almost immediately after the creation became the object of criticism from the advocates of classicism. D.A. Miliutin recalled that the main purpose of D.A. Tolstoy was "to humiliate real education and not to allow it to compete with his favorite classical course of gymnasiums" and "this goal was achieved completely" [15]. In the society there was implanted the idea of a low level of education in real training schools in comparison with the gymnasium, although this was not always true. Among the students of real training schools there were many wellknown scientists, engineers, people of culture: academician A.F. Ioffe, the founder of chemical physics, the Nobel Prize winner N.N. Semenov, mechanical scientist S.P. Tymoshenko, the "father of television" V.K. Zvorykin, biologists A.A. Lyubishchev and A.L. Chizhevsky, the designer of nuclear reactors N.A. Dollezhal, philosopher F.A. Stepun and writer V.M. Garshin.

In the best real training schools, Russian and modern foreign languages were well taught, great attention was paid to the aesthetic education of students. They could learn to play musical instruments, participate in literary and musical evenings, theatrical productions. The creation of real training schools made it possible to get secondary education for children in small towns, in which there were no gymnasiums. For example, future academicians A.F. Ioffe and S.P. Tymoshenko were classmates in a modest real training school in Romny, Poltava province. V.K. Zvorykin graduated with honors from a real training school in a quiet provincial Murom. Future designer of nuclear reactors N.A. Dollezhal studied in a real training school in Podolsk near Moscow, where, at the invitation of its director V.N. Fleury lessons of mathematics, chemistry and physics were given by famous Russian scientists.

The social composition of students in real training schools was more democratic than in the gymnasiums, where there mainly studied the children of noblemen and civil servants. For example, from 1880 to 1892 the share of children of nobility and officials among students in gymnasiums and progymnasiums increased from $47.6 \%$ to $56.2 \%$. During the same period, their share in real training schools fell from $44 \%$ to $38 \%$. At the same time, the number of natives from urban strata grew in real training schools by $6 \%$ [16].

The engineering corps in Russia was largely formed from former graduates of real training schools, who after that graduated from technical universities. And, unlike the graduates of gymnasiums who entered universities without entrance examinations, they had to go through a rigorous competitive selection. In 1882 for admission to the Imperial Moscow Technical School it was necessary to pass examinations in mathematics, physics, drawing, painting, essay writing. Examinations in mathematics and physics were taken based on the gymnasium program, drawing and painting were based on the course of the real training school [17].

According to the data for the 1912-1913 academic year, graduates of real training schools accounted for $44 \%$ of students in mining institutes and polytechnics of the Ministry of Industry and Trade [18]. On the other hand, these figures indicate that the majority of students in technical colleges received secondary education in classical gymnasiums, which gave good training not only in humanitarian subjects, but also in mathematics and natural science. Consequently, the opposition of classical education to the real one was of an artificial nature.

Appointed in March 1882 Minister of Public Education I.D. Delyanov continued the policy of D.A. Tolstoy. He believed that real training schools did not provide sufficient training for either practical work or for entering technical colleges. Prejudiced against the real schools was Alexander III, who considered it "really harmful and very undesirable" to allow graduates of real training schools to enter universities [19].

On November 27, 1886, a "Draft Plan of Industrial Education" was submitted to the State Council for consideration. It stated the grounds for reforming the real training schools. The Ministry of Public Education intended to shorten the training period in real training schools to 5 years and to deprive their graduates of the right to enter any universities. Such plans were contrary to the public opinion. Most of the members of the State Council did not agree with them. Taking this into account, the changes in the «Statute of Real Training Schools» approved on June 9, 1888, retained for them the status of general educational institutions, although they were lower in comparison with gymnasiums [20].

\section{CONCLUSION}

Only during the first Russian revolution the Ministry of Public Education was forced to make concessions to the public. On March 18, 1906 it was allowed to admit to universities the graduates of real and commercial training schools on condition that they pass additional exams for the course of the gymnasium. But attempts to bring this intradepartmental normative act to the all-Russian legislative level failed [21].

Discussion between supporters and opponents of real education in the second half of the 19th century was the reflection of the struggle for the choice of the vector of developing education in Russia. The socio-economic development of the country required the modernization of the secondary school to bring it in line with the progress of science and technology. However, instead of seeking a reasonable correlation of the strengths of classical and real 
education, the discussion acquired the character of the opposition of real education to the humanities and the identification of the latter with the study of ancient languages. This dispute was not resolved in Russia until 1917.

\section{REFERENCES}

[1] History of crafts, technical sciences and industry in Russia in a social context: a textbook / I.L.Abramova, B.N.Zemtsov, E.N.Budreiko, V.L.Gvozdetsky, D.V. Lobach, T.R.Suzdaleva, K.V.Fedorov;] Ed. B.N.Zemtsova. Moscow: Publishing House MSTU. named after N.E.Bauman, 2017, pp. 82-91.

[2] V.Y. Ivlev, M.L. Ivleva, Boundaries of influence of Moscow and Kiev cultural and philosophical traditions in pre-Petrine and Petrine era. In: Proceedings of Moscow State University of Mechanical Engineering (MAMI), 2014. № 2 (20), pp. 95-99; R.A. Ignatieva, Formation and development of real education in Russia in the late XIX - early XX century. Dis. ... cand. ped. sciences. - M., 2007; V.N. Lipnik. School reforms in Russia. Characteristics of School Reforms in Pre-Revolutionary Russia // Education. - 2003. № 4; V.D.Pavlidis. Mathematical education in real gymnasiums and colleges in Russia XIX - early XX centuries. Dis. ... Doctor of Science. Magnitogorsk, 2006; I.V.Siniushina. Development of real education in Russia in the XIX - early XX century. M.: Prometheus, 2006; K.V.Fedorov, T.R.Suzdaleva. Real education in the context of the historical development of Russia in the second half of the XIX - beginning of the twentieth century in Russia // The Humanitarian Journal of the Moscow State Technical University named after N.E.Bauman. - 2016. No. 5 (43).

[3] N.I. Pirogov, Questions of life / / Marine collection. 1856. V. XXIII, Book 9, p. 571.

[4] M.N. Katkov, The ideology of protection. Moscow: Institute of Russian Civilization, 2009, pp. 481-482.

[5] Ibid., p. 27.

[6] K.D. Ushinsky, Pedagogical works of N.I. Pirogov // K.D. Ushinsky. Collected works in 6 volumes - V.3. M.-L.: Publishing House of the Academy of Pedagogical Sciences of the RSFSR, 1948, pp. 46-47.

[7] A.I. Aleshintsev, History of gymnasium education in Russia in XVIII-XIX centuries. - SPb .: Publishing house of O. Bogdanova, 1912, p. 217.

[8] Summary of printed reviews of the draft Statute of lower and secondary schools, members of the Ministry of Public Education / / Journal of the Ministry of Education. Part CIX. 1861. January. P. 149-189; 1861. March, pp. 244-310.

[9] V.Y. Ivlev, M.L. Ivleva, Peculiarities of Aristotelian scholastic logic. In: Proceedings of the 2017 2rd International Conference on Contemporary Education, Social Sciences and Humanities 2017, pp. 91-95.

[10] S.V. Rozhdestvensky, Historical overview of the activities of the Ministry of Public Education. 1802 - 1902. SPb .: Publication of the Ministry of Public Education, 1902, . 436

[11] Statute of gymnasiums and progymnasium departments of the Ministry of National Education / / Journal of the Ministry of Public Education. 1864. December. Part CXXIV, p.70.

[12] A.A. Kornilov, The course of the history of Russia in the XIX century. M .: Higher School, 1993, p. 304.

[13] S.V. Rozhdestvensky, Historical overview of the activities of the Ministry of Public Education. 1802 - 1902, pp. 519-527.

[14] The statute of real training colleges of the Ministry of Public Education // Journal of the Ministry of Public Education. 1872, June, Part CLXI, p. 52.

[15] D.A. Milutin, Diary: in 4 volumes - V.4. 1882 - 1883. - M .: State University. Library of V.I. Lenin, 1950, p.128.

[16] Sh.I. Ganelin, Essays on the history of secondary school in Russia in the second half of the XIX century. Moscow: Education, 1954, p.103.

[17] G.N. Antsupova, G.P.Pavlikhin. Rectors of the Moscow State Technical University named after N.E.Bauman (1830 - 2001).
Moscow: Publishing House MSTU named after N.E.Bauman, 2002, p 51.

[18] [18] A.E. Ivanov, Higher School of Russia in the late XIX - early XX century. M .: Academy of Sciences of the USSR, Institute of Soviet History, 1991, pp. 260-261.

[19] Sh.I. Ganelin, Essays on the history of secondary school in Russia in the second half of the XIX century, pp. 98-99.

[20] S.V.Rozhdestvensky, Historical overview of the activities of the Ministry of Public Education. 1802 - 1902, p. 644.

[21] A.E. Ivanov, Higher School of Russia in the late XIX - early XX century, p. 263. 